\title{
Wyimki z dziennika terenowego
}

28.04.2020 r.

Podczas pandemii realizuję badania etnograficzne online. Wrzucam ogłoszenie na stories:

Cześć. Piszę doktorat na temat urazów twarzy osób z doświadczeniem życia jako kobiety i szukam rozmówczyń do wywiadów etnograficznych, tj. tych, którzy i które mają za sobą wypadek i w jego wyniku inną twarz (w drobnym bądź znaczącym stopniu). Byłoby mi niesamowicie miło, gdybyś zgodziła się na rozmowę. Gwarantuję bezpieczeństwo i anonimowość. Kilka zdań o moich badaniach: zastanawiam się m.in. jak nagłe zmiany cielesne/tożsamościowe wpływają na strategie i praktyki życia społecznego, rozkładam piękno na czynniki pierwsze i staram się walczyć z kanonami/oczekiwaniami wobec „kobiecych” twarzy. Sama ponad 2 lata temu miałam wypadek samochodowy, w wyniku którego moja twarz bardzo się zmieniła i dlatego teraz się tym zajmuję.

Będę wdzięczna za pomoc! Serdeczne pozdrowienia, Wika Krauz

Moja działalność na Facebooku i Instagramie nieoczekiwanie przynosi szybkie efekty. Pomaga mi wielu znajomych oraz nieznajomych, którzy udostępniają post i wyraźnie wspierają akcję. Odzywa się sporo osób, m.in. koleżanka ze studiów, która nie lubi zdjęć, pozwalających zauważyć ułamany ząb, znajoma znajomej, która kiedyś dostała końskim kopytem w policzek, albo artystka, która podczas ataków epilepsji regularnie, w pełni nieświadomie, robi sobie na twarzy siniaki.

Myślę o tym, że nigdy wcześniej nie prowadziłam wywiadów online. Przez wiele lat rozmawiałam $\mathrm{z}$ różnymi osobami przeważnie $\mathrm{w}$ ich domach. Teraz też mnie do nich zapraszały, ale w nieco inny sposób. W prostokąciku na ekranie komputera pokazywały mi fragmenty swoich ogrodów, mieszkań, pokojów, łóżek, kanap, a nawet obrazy na ścianach, ale trudno było mi je osadzić w większej przestrzeni. W warunkach cyfrowych kobiety zyskiwały większą decyzyjność i kontrolę nad 
własnym otoczeniem oraz wizerunkiem. Same wyrażały zgodę na pokazywanie twarzy, a do tego w każdej chwili mogły wyłączyć funkcję wideo i tym samym dać znać, że nie chcą być podglądane.

Zastanawiałam się, co stało się z ciałami moich rozmówczyń. Nagle zniknęły. W kamerce rzadko mogłam zobaczyć choćby rękę albo nogę. Przeważnie pojawiała się sama twarz w dużym zbliżeniu. Była nieco rozmazana i rozpikselowana, co nas wszystkie trochę denerwowało. Przez to nie mogłyśmy pokazać sobie własnych blizn ani zniekształceń tak dokładnie jak w rzeczywistości analogowej. Kiedy rozmawiałyśmy online o kształcie czy strukturze blizny, zbliżałyśmy swoje twarze do internetowych kamerek tak, żeby druga osoba mogła zobaczyć wszystko ze szczegółami. Nieregularne formy po ranach ciętych czy szarpanych zazwyczaj trudno opisać, dlatego łatwiej je po prostu pokazać. Wówczas czułam, że tworzy się między nami niesamowita płaszczyzna porozumienia. Po obu stronach pękały bariery wstydu, niepewności, niemocy, świadomości nienormatywności, które tak dobrze znałyśmy z wielu sytuacji społecznych. Dawałyśmy sobie bezpieczeństwo tym pokazywaniem.

Wczoraj rozmawiałam z jedną kobietą, z M.S. Sama trafiłam na nią w Internecie i myślę, że to był pierwszy tak obszerny i szczery wywiad, w którym bardzo świeże emocje wyszły na wierzch. Szczególnie poruszyło mnie to, kiedy M.S. opowiadała, jak musiała odrywać zranione, zakrwawione ucho od poduszki, bo zdążyło się z nią skleić. Perspektywa połączenia ciała z materiałem i brak kontroli nad wydzielinami, które z nas wypływają, przypomniały mi o czasie własnej rekonwalescencji. M.S. mówiła także, że ma siostrę bliźniaczkę, w której po wypadku widziała swoje odbicie. Przeglądała się w jej twarzy oraz ciele jak w zakrzywionym lustrze i wyła przez to z (meta)fizycznego bólu. Odniosłam wrażenie, że do życia napędzało ją głównie pragnienie zmian i absolutnie nie zamierzała zaakceptować poparzeń, które aktualnie ją budują. Prawdopodobnie rozmawiałybyśmy inaczej, gdyby nie tzw. lockdown i możliwość rozmowy bez pokazywania twarzy. No właśnie, tylko jak?

Dziś dostałam mail ze zdjęciami od dziewczyny, która padła ofiarą źle przeprowadzonego zabiegu dermatologicznego. Przesłała fotografie blizny w okolicy skroni na różnych etapach gojenia się i zrastania skóry. Przywołała niezwykle ciekawy kontekst kulturowo-społeczny, m.in. podróż do Japonii, tymczasowe mieszkanie w Azji i tamtejsze bezpieczeństwo. Opowiedziała o tzw. safe space, jaki wytworzyli ludzie, których tam poznała. Napisała, że w Japonii komentowanie wyglądu twarzy jest uznawane za bardzo głębokie wejście w cudzą sferę prywatną, dlatego nikt tego nie robi. Ludzie podchodzą do siebie $\mathrm{z}$ wyjątkowo dużą empatią i tym samym pokazują, że takie niewielkie symptomy nienormatywności nie mają dla nich znaczenia w relacjach.

Dziś też jest rocznica mojego wypadku. Nie bardzo wiem, jak się z tym czuję. Trochę dziwnie, a na pewno trochę spokojniej niż tego samego dnia kilka lat wstecz. Co ciekawe, trzy lata temu również spędzałam końcówkę kwietnia i cały maj 


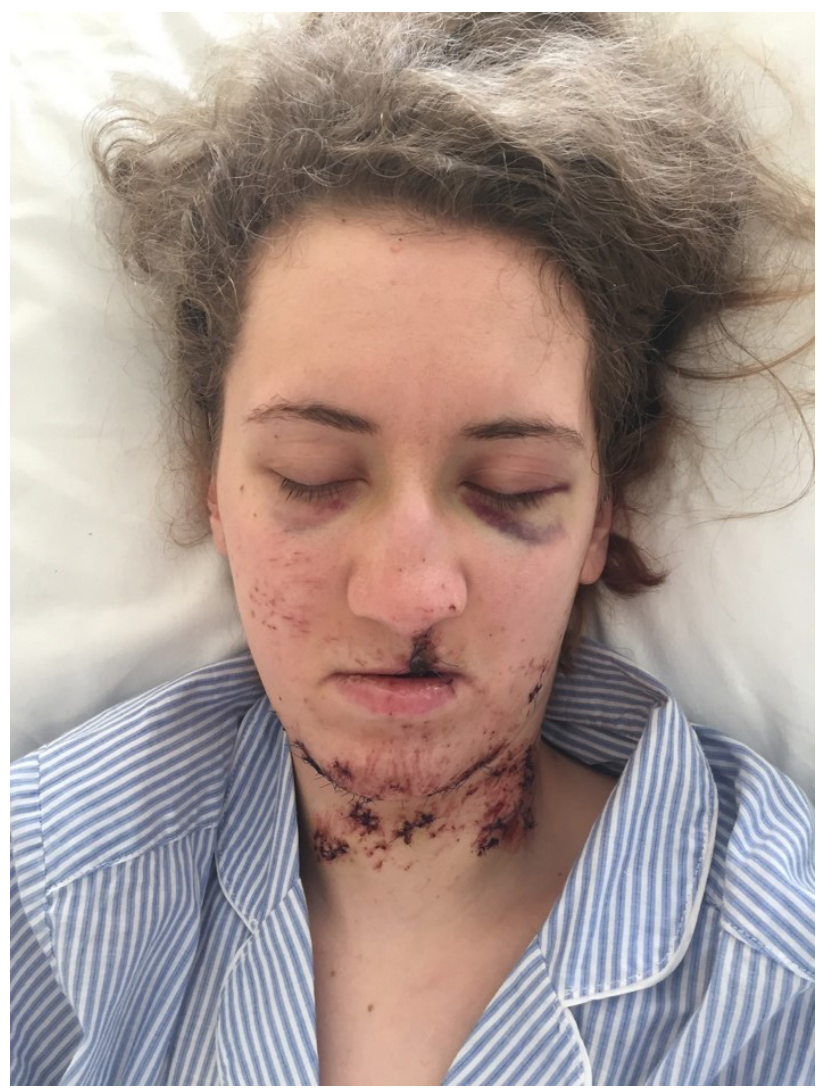

w izolacji, ale bardziej metaforycznej. Byłam świeżo po wypadku, po poważnym urazie twarzy, po którym czułam się ogołocona z własnej tożsamości i zamknęłam się wewnątrz samej siebie. Idąc dziś do sklepu, zamaskowana, odczuwałam niepokój. Szczególnie podczas przechodzenia przez ulicę. Bałam się, że nadjeżdżający samochód coś mi zrobi, że trafię do szpitala i znów trzeba będzie składać moją twarz. Teraz zdałam sobie sprawę z tego, że to chyba moja podstawowa obawa. Nie to, że w ogóle cokolwiek kiedykolwiek może mi się stać, ale to, że konsekwencją każdego nienormatywnego, bolesnego, chorobowego, losowego zdarzenia może być utrata obecnej twarzy, do której w jakimś sensie już się przyzwyczaiłam. Boję się, że znów będę musiała przechodzić przez to samo, że będzie jeszcze gorzej, niż było za pierwszym razem - boleśniej, brzydziej, dłużej, bardziej wykluczająco. Czy moje rozmówczynie mają podobne obawy?

$\mathrm{Z}$ jednej strony rozgrzebywanie tych wszystkich wspomnień - moich i wytworzonych na podstawie cudzych narracji - daje mi siłę i wreszcie czuję, że inni mają podobnie, że ktoś naprawdę jest w stanie mnie zrozumieć. Czuję też, że bardzo pomagam moim rozmówczyniom. Pandemia dała mi mnóstwo nowych ba- 
dawczych możliwości. Pozwoliła na pokonanie barier czasowych oraz dystansu geograficznego pomiędzy mną a moimi rozmówczyniami i sprawiła, że dotarłam do osób, które w sytuacji przed tzw. lockdownem byłyby dla mnie niedostępne. Przymusowa kwarantanna zatrzymała te osoby w domach i tym samym zachęciła do opowiadania o własnych doświadczeniach. Życie nieco zwolniło, można było się zatrzymać i skupić na sobie.

$\mathrm{Z}$ drugiej strony są to badania potwornie obciążające i nie mogę pozwolić sobie na więcej niż jeden wywiad w ciągu jednego/dwóch tygodni. Mam nieustanną potrzebę regeneracji i szukam różnych form etnograficznej superwizji. Czymś takim może być dla mnie np. rozmowa i konsultacja ze znajomymi, bardziej doświadczonymi badaczkami, podczas której analizujemy zebrane materiały. Świetną przestrzenią na ułożenie myśli jest też dla mnie rozmowa z bliskimi, z którymi razem przechodziliśmy przez wszystkie etapy rekonwalescencji po moim wypadku. Od tych osób wciąż dostaję mnóstwo emocjonalnego wsparcia i odnoszę wrażenie, że dzięki temu wiem, jak dawać je moim rozmówczyniom. 